\title{
Effects of straw returning with potassium fertilizer on the stem lodging resistance, grain quality and yield of spring maize (Zea mays L.)
}

Ya-fang Fan ${ }^{1, \dagger}$, Ju-lin Gao ${ }^{1,}$, Ji-ying Sun ${ }^{1,}$, Jian $\mathrm{Liu}^{2}$, Zhi-jun $\mathrm{Su}^{1}$, Shu-ping $\mathrm{Hu}^{2}$, Zhi-gang Wang ${ }^{1}$, Xiao-fang $\mathrm{Yu}^{1}$

1 College of Agronomy, Inner Mongolia Agricultural University, No.275, XinJian

East Street, Hohhot 010019, China;

2 Vocational and Technical College, Inner Mongolia Agricultural University, Baotou 014109, China;

* Correspondence author: Julin Gao, Email: nmgaojulin@163.com (J.-1.G.); Tel.: $+86-139-4713-0409$

$\dagger \quad$ Y.F. Fan and J.Y. Sun contributed equally to the work.

Abstract: The effects of straw returning with potassium fertilizer on the stem lodging resistance, grain quality and yield of spring maize were investigated to provide a scientific basis for the rational utilization of Inner Mongolia spring maize straw and potassium fertilizer resources. This study utilized Xianyu 335 as the test material, and a split plot design was carried out in three ecological regions from eastern to western Inner Mongolia (Tumochuan Plain irrigation area, Hetao Plain irrigation area and Lingnan warm dry zone), with the straw returning method as the main plot and potassium fertilizer dosage as the subplot. The stem resistance index, grain quality and yield were systematically identified. Both application of potassium fertilizer and straw returning improved the resistance and yield indicators of spring maize. Straw returning increased the effectiveness of potassium fertilizer application on spring maize plant height, ear height, fresh weight of stems, brix of stems and stem puncture strength by $2.82 \%-5.22 \%, 3.11 \%-5.90 \%, 15.96 \%-19.78 \%, 4.35 \%-4.50 \%$ and $8.89 \%-14.82 \%$, respectively. Straw returning increased the effectiveness of potassium fertilizer application on the spring maize grain protein content, spring maize grain crude fat content, maize yield and yield variation coefficient by $3.49 \%-6.50 \%, 2.09 \%-4.43 \%, 4.87 \%-12.50 \%$ and $5.07 \%-7.55 \%$, respectively. Straw returning can be combined with reasonable application of potassium fertilizer to increase the effectiveness of potassium fertilizer and enhance lodging resistance. Along with increased maize yield, straw returning also improves grain quality and enhances yield stability, providing a theoretical basis for high-yield and 
stress-resistant cultivation of Inner Mongolia spring maize, which can be popularized and applied in the spring maize planting areas of Inner Mongolia.

Keywords: Maize; straw returning; potassium fertilizer; lodging resistance; grain quality

\section{Introduction}

As the most popular grain crop in China, the yield and quality of maize (Zea mays L.) must be maintained at high levels to ensure stable increases in national grain production and food security [1]. With the continuous adjustment and improvement of the goals and tasks of the maize planting industry in China, priorities have changed from the pursuit of high yield alone to a broader focus on optimizing structure and enhancing quality while controlling cost. Therefore, current agricultural strategies are aimed at adjusting planting modes, improving the quality of maize products, and promoting the ecologically responsible and high-quality development of the planting industry on the basis of ensuring a stable increase in grain production.

Lodging is a major factor that limits maize yields. According to reports from the previous decade $[2,3]$, the lodging rate of maize is significantly positively correlated with ear height, and yield decreases by $108 \mathrm{~kg} / \mathrm{hm}^{2}$ for every increase of $1 \%$ in the lodging rate during maize production. Mechanical properties associated with maize stem lodging resistance are important indicators of the degree of lodging resistance of maize plants and are significantly negatively correlated with field lodging rates. The phenotypic traits of stems influence mechanical properties associated with lodging resistance and thus determine the lodging resistance of plants [4-6]. In response to the direction in which grain production practices are developing in China, stable production and guaranteed income require enhancement of grain development, improvement in maize grain quality, and increased economic efficiency. The quality of maize grain is altered by long-term fertilization [7]. In addition, grain quality is influenced by genetics, fertilization measures and environmental conditions [8]. The practice of returning straw to maize fields provides abundant organic substances, which can promote the synthesis of crude fat, protein and starch in maize grain and improve grain quality [9].

The application of potassium fertilizer can improve maize resistance to lodging, enhancing quality and increasing maize yield [10]. However, due to a lack of potassium resources in China, potassium fertilizer is generally imported, leading to high cost and limited availability. The effectiveness of $\mathrm{K}^{+}$in soil and fertilizer is dependent on the soil texture [11]. To overcome the increasingly serious problem of soil potassium deficiency, effective means of supplementing soil potassium in addition to fertilizer 
potassium are required. With the current level of soil productivity, there is a need to explore the production potential of the soil itself in order to increase the nutrient level of the soil, improve the soil structure and physicochemical properties, optimize the ecological environment of the farmland, and maintain high crop yields, with the goal of avoiding resource waste and environmental pollution [12-14]. The direct burning, abandonment or incineration of straw resources causes significant environmental pollution and represents a significant waste of resources. Therefore, straw returning is a method of achieving comprehensive utilization of straw resources [15]. Straw returning can optimize soil structure and physical and chemical properties, improve soil enzyme activity, and increase soil nutrients and maize yield $[16,17]$. China is rich in straw resources. The average annual yield of maize straw in China is 399.18 million $\mathrm{t}$, and the potassium nutrient content provided by maize straw returning in China is 4.79 million $t \mathrm{~K}_{2} \mathrm{O}$. The potassium fertilizer substitution potential of maize straw returning in the growing season in China is $24.4 \mathrm{~kg} / \mathrm{hm}^{2} \mathrm{~K}_{2} \mathrm{O}$ [18], and the release rate of potassium during this season is approximately $85 \%$ [19]. It is generally believed that the use of straw resources can alleviate soil potassium deficiency and enrich the soil potassium pool, which should improve soil fertility and allow growers to meet the potassium demand of maize production in China.

Previous studies mostly focused on adding potassium fertilizer to increase the yield of maize based on straw returning $[20,21]$. However, there are few studies on the effects of straw returning with potassium fertilizer on the stem lodging resistance, grain quality and yield of spring maize. The effects of straw returning with potassium fertilizer on the phenotypic traits, stem lodging resistance mechanical properties, maize grain quality and yield of spring maize were investigated in three ecological regions from eastern to western Inner Mongolia, and a cultivation model suitable for high-quality and high-yield maize agriculture was explored. This study provides a basis for the cultivation of high-yield and stress-resistant spring maize in Inner Mongolia and elsewhere in China, as well as the development of a high-quality green planting industry.

\section{Materials and Methods}

\section{Overview of the test site}

Three ecological regions in Inner Mongolia (Tumochuan Plain irrigation area, Hetao Plain irrigation area and Lingnan warm dry zone) were used as test sites in 2019. The longitude and 
latitude, sunshine hours from April to October, average temperature, and rainfall at each test site are listed in Table 1. Table 2 shows the soil type and basic soil fertility of each test site.

Table 1 Latitude and longitude and climatic conditions of three ecological regions in Inner Mongolia

\begin{tabular}{|c|c|c|c|c|c|c|}
\hline Ecological region & $\begin{array}{c}\text { Experimental } \\
\text { sites }\end{array}$ & Latitude & Longitude & $\begin{array}{c}\text { Solar } \\
\text { radiation } \\
\text { (hour) }\end{array}$ & $\begin{array}{c}\text { Average } \\
\text { temperature } \\
\left({ }^{\circ} \mathrm{C}\right) \\
\end{array}$ & $\begin{array}{l}\text { Precipitation } \\
\text { (mm) }\end{array}$ \\
\hline Hetao Plain irrigation area & Bayannur & $41^{\circ} 11^{\prime} \mathrm{N}$ & $122^{\circ} 49^{\prime} \mathrm{E}$ & 1924.3 & 20.4 & 157.6 \\
\hline $\begin{array}{c}\text { Tumochuan Plain irrigation } \\
\text { area }\end{array}$ & Baotou & $40^{\circ} 32^{\prime} \mathrm{N}$ & $122^{\circ} 48^{\prime} \mathrm{E}$ & 1716.4 & 21.1 & 317.7 \\
\hline Lingnan warm dry zone & Xing'an & $46^{\circ} 45^{\prime} \mathrm{N}$ & $122^{\circ} 47^{\prime} \mathrm{E}$ & 1330.5 & 22.3 & 392.5 \\
\hline
\end{tabular}

Table 2 Soil type and soil basic fertility of three ecological regions in Inner Mongolia

\begin{tabular}{|c|c|c|c|c|c|c|c|}
\hline Ecological region & Soil type & $\begin{array}{l}\text { Organic Matter } \\
(\mathrm{g} / \mathrm{kg}) \\
\end{array}$ & $\begin{array}{l}\text { Total N } \\
(\mathrm{g} / \mathrm{kg}) \\
\end{array}$ & $\begin{array}{l}\text { Available N } \\
(\mathrm{mg} / \mathrm{kg}) \\
\end{array}$ & $\begin{array}{l}\text { Olsen P } \\
(\mathrm{mg} / \mathrm{kg}) \\
\end{array}$ & $\begin{array}{l}\text { Available K } \\
(\mathrm{mg} / \mathrm{kg}) \\
\end{array}$ & $\mathrm{pH}$ \\
\hline $\begin{array}{c}\text { Hetao Plain irrigation } \\
\text { area }\end{array}$ & $\begin{array}{l}\text { Irrigated } \\
\text { soil }\end{array}$ & 26 & 0.4 & 87.5 & 6.6 & 140.3 & 7.9 \\
\hline $\begin{array}{c}\text { Tumochuan Plain } \\
\text { irrigation area }\end{array}$ & Silty loam & 26.7 & 0.5 & 92.4 & 8.8 & 118 & 7.6 \\
\hline $\begin{array}{l}\text { Lingnan warm dry } \\
\text { zone }\end{array}$ & Black soil & 29.1 & 1.3 & 100.6 & 13.7 & 112.8 & 7.8 \\
\hline
\end{tabular}

The field study was carried out on the official land which belonged to the key laboratory of crop cultivation and genetic improvement of Inner Mongolia Autonomous Region, permission was given after research application passing verification. During the field study none of endangered or protected species were involved. No specific permissions were required for conducting the field study because it was not carried out in protected area.

\section{Experimental design}

This study utilized Xianyu 335 as the test material in a split plot design, with the straw returning method as the main plot and potassium fertilizer dosage as the subplot. The 4 treatments used in the study were straw returning + potassium fertilizer $(\mathrm{ST}+6 \mathrm{~K})$, straw returning + no potassium fertilizer $(\mathrm{ST}+0 \mathrm{~K})$, no straw returning + potassium fertilizer $(\mathrm{NST}+6 \mathrm{~K})$, and no straw returning + no potassium fertilizer (NST+0K). The row length was $30 \mathrm{~m}$, the row width was $5 \mathrm{~m}$, and the row spacing was $0.60 \mathrm{~m}$. 
Five replicates were used in this experiment, and the planting density was $82500 \mathrm{plants} / \mathrm{hm}^{2}$. The straw returning treatments utilized pulverized straw that was returned to the field in the autumn of the previous year. The non-returning treatments were all household shallow rotation modes. Potassium was applied as $90 \mathrm{~kg} / \mathrm{hm}^{2}$ potassium sulfate $\left(\mathrm{K}_{2} \mathrm{O} 50 \%\right)$ and $228 \mathrm{~kg} / \mathrm{hm}^{2}$ diammonium phosphate $\left(\mathrm{P}_{2} \mathrm{O}_{5} 46 \%\right)$ once as the base fertilizer before sowing. For the treatments without potassium, only $228 \mathrm{~kg} / \mathrm{hm}^{2}$ diammonium phosphate $\left(\mathrm{P}_{2} \mathrm{O}_{5} 46 \%\right)$ was applied once as the base fertilizer before sowing. The top dressing of each treatment was $652 \mathrm{~kg} / \mathrm{hm}^{2}(\mathrm{~N} 46 \%)$, which was applied in the jointing stage and the bell stage at a ratio of 3:7. Other management procedures followed typical field production practices.

\section{Measurement items and methods}

Before sowing, 0-20 cm soil samples were taken for each treatment, ventilated and dried in a cool place, after which they were ground to pass through a $0.15-0.25 \mathrm{~mm}$ soil sieve. According to the measurement requirements, soil samples with different particle sizes were used to determine soil essential nutrients [22].

(1) Soil organic matter determination was performed using the potassium dichromate titration method. (2) Soil total nitrogen determination was performed using a Kjeldahl nitrogen analyzer (K-9840, Jinan) and the semi-micro Kjeldahl method. (3) Soil available phosphorus determination was performed using the $\mathrm{NaH}_{2} \mathrm{CO}_{3}(0.5 \mathrm{~mol} / \mathrm{L}) \mathrm{Mo}-\mathrm{Sb}$ colorimetric method. (4) Soil available potassium determination was performed using the $\mathrm{NH}_{4} \mathrm{Ac}(1 \mathrm{~mol} / \mathrm{L})$ extraction 30 -min flame photometric method. (5) Soil alkaline hydrolysis determination was performed using the alkaline hydrolysis diffusion-absorption method.

The following stem indicators were measured during the silking period. (1) Plant height was measured by using a steel ruler to measure the distance from the top of the tassel to the ridge side. (2) Ear height was measured by using a steel ruler to measure the distance between the first ear internode and the ridge side. (3) Stem diameter was measured by using a Vernier caliper to measure the third stem node at the stem base part. (4) Ear stem length was determined by measuring the maize ear node length. (5) Stem fresh weight was determined by measuring the maize stem fresh weight. (6) Stem dry weight was determined by measuring the weight of dried maize stems. (7) The water content of the stems was calculated as the ratio of (stem fresh weight-stem dry weight) and stem fresh weight. (8) To measure the brix of the stems, the maize stems were extracted and mixed, and 1-2 $\mathrm{mL}$ of the mixture was measured with a handheld digital sugar meter (PAL-1, Japan ATAGO, accuracy $= \pm 0.2 \%$ ). (9) To assess stem 
lodging resistance mechanical indicators, the stem puncture strength, compressive strength and bending strength of the third stem node at the maize stem base were measured with a plant stem strength instrument (YYD-1, Tuopu Yunnong, Zhejiang, accuracy $= \pm 0.5 \%$ F.S.).

The starch content, crude fat content, protein content, and water content of maize grains were measured with a FOSS near-infrared grain quality analyzer (Infratee TM 1241, FOSS, Denmark) at maturity.

At the physiological maturity stage, two rows in the middle of the measured production area were selected, and all plants in these rows were harvested after removal of the side plants. The number of harvested ears was counted. Ten plants with uniform ear growth were selected for determination of ear rows, row grains, 1000-grain weight, and grain water content (measured with an LDS-1G moisture content detector), which were converted into maize yield (converted into hectare yield with $14 \%$ water content).

\section{Data statistical analysis}

Data SPSS window version 17 (SPSS Inc., Chicago, USA) was used to finishing statistical analysis. Under straw-return treatments, potassium fertilizer treatments, and ecological regions, we examine stem lodging resistance, grain quality and yield of spring maize using GLM based on the model for a split-plot design [23]. The values were all the mean squares (MS) of the ANOVA. Straw-return treatments, potassium fertilizer treatments, and ecological regions were the independent variables, and the stem lodging resistance, grain quality and yield of spring maize were dependent variables in this test. In order to determine the impact of independent variables on dependent variables, statistically significant variance was tested using three-way analysis of variance, and multiple comparisons were made using the least significant difference (LSD) test with $\alpha=0.05$ [24]. Histograms were conducted by using Sigma Plot 12.5. And different letters on histograms indicated that means statistically different at $\mathrm{P}<0.05$ level.

\section{Results}

Effects of straw returning combined with potassium fertilizer on the morphological indexes of spring maize stems 
As shown in Table S1, the effects of variation of the straw returning method, potassium fertilizer dosage, and ecological region on plant height, ear height, stem diameter and ear stem length reached an extremely significant level. The effects of the interaction of the straw returning method and potassium fertilizer dosage on the above-mentioned indicators reached a very significant level. The effect of the interaction of the straw returning method and ecological region and the interaction of the potassium fertilizer dosage and ecological region on plant height, stem diameter and ear stem length reached a significant or extremely significant level. The effect of the interaction of the straw returning method, potassium fertilizer dosage and ecological region on plant height reached an extremely significant level.

Table S1 ANOVA results for maize stem morphological indicators under different straw returning methods and potassium fertilizer treatments

\begin{tabular}{|c|c|c|c|c|c|}
\hline Source of variation & $\begin{array}{c}\text { Plant height } \\
(\mathrm{cm})\end{array}$ & $\begin{array}{c}\text { Ear height } \\
(\mathrm{cm})\end{array}$ & $\begin{array}{l}\text { Ear height } \\
\text { coefficient }\end{array}$ & $\begin{array}{c}\text { Stem meter } \\
(\mathrm{mm})\end{array}$ & $\begin{array}{c}\text { Stem length } \\
(\mathrm{cm})\end{array}$ \\
\hline Straw returning method (S) & $1539.66^{* *}$ & $160.66^{* *}$ & ns & $19.80^{* *}$ & $10.53 * *$ \\
\hline Potassium fertilizer dosage (K) & $6119.79 * *$ & $1060.42 * *$ & ns & $44.63 * *$ & $23.18 * *$ \\
\hline Ecological region (E) & $444.16^{* *}$ & $153.68^{* *}$ & $* *$ & $41.34 * *$ & $0.95 * *$ \\
\hline $\mathrm{S} \times \mathrm{K}$ & $540.72 * *$ & $99.12 * *$ & ns & $6.19 * *$ & $1.08 * *$ \\
\hline $\mathrm{S} \times \mathrm{E}$ & $67.48 * *$ & $8.01 \mathrm{~ns}$ & ns & $0.16^{*}$ & $0.18 * *$ \\
\hline $\mathrm{K} \times \mathrm{E}$ & $21.30^{* *}$ & $2.86 \mathrm{~ns}$ & ns & $0.34 * *$ & $0.03 *$ \\
\hline $\mathrm{S} \times \mathrm{K} \times \mathrm{E}$ & $19.92 * *$ & $4.08 \mathrm{~ns}$ & ns & $0.04 \mathrm{~ns}$ & $\mathrm{~ns}$ \\
\hline
\end{tabular}

As shown in Table 3, maize plant height, ear height, ear stem diameter and ear stem length varied among the treatment groups. In the Tumochuan Plain irrigation area, under the straw returning treatment, the maize plant height, ear height, ear height coefficient, stem diameter and ear stem length increased by $7.74 \%, 8.36 \%, 0.57 \%, 8.57 \%$, and $11.24 \%$, respectively, with potassium application in comparison with no potassium application. With no straw returning treatment, the maize plant height, ear height, ear height coefficient, stem diameter and ear stem length increased by $4.92 \%, 5.25 \%, 0.31 \%$, $4.14 \%$, and $7.21 \%$, respectively, with potassium application in comparison with no potassium application. Straw returning improved the effectiveness of potassium application on the maize plant 
height, ear height, ear height coefficient, stem diameter and ear stem length by $2.82 \%, 3.11 \%, 0.26 \%$, $4.43 \%$ and $4.03 \%$, respectively.

In the Hetao Plain irrigation area, with the straw returning treatment, the maize plant height, ear height, ear height coefficient, stem diameter and ear stem length increased by $9.94 \%, 10.65 \%, 0.64 \%$, $9.74 \%$, and $12.03 \%$, respectively, with potassium application in comparison with no potassium application. With no straw returning, the maize plant height, ear height, ear height coefficient, stem diameter and ear stem length increased by $4.72 \%, 4.75 \%, 0.03 \%, 5.39 \%$, and $8.62 \%$, respectively, with potassium application in comparison with no potassium application. Straw returning increased the effectiveness of potassium application on the maize plant height, ear height, ear height coefficient, stem diameter and ear stem length by $5.22 \%, 5.90 \%, 0.62 \%, 4.35 \%$ and $3.41 \%$, respectively.

In the Lingnan warm dry zone, under the straw returning treatment, the maize plant height, ear height, ear height coefficient, stem diameter and ear stem length were increased by $8.02 \%, 8.78 \%$, $0.71 \%, 9.42 \%$, and $11.76 \%$, respectively, with potassium application in comparison with no potassium application. With no straw returning, the maize plant height, ear height, ear height coefficient, stem diameter and ear stem length were increased by $4.48 \%, 4.90 \%, 0.40 \%, 3.36 \%$, and $7.80 \%$, respectively, with potassium application in comparison with no potassium application. Straw returning increased the effectiveness of potassium application on the maize plant height, ear height, ear height coefficient, stem diameter and ear stem length by $3.54 \%, 3.88 \%, 0.31 \%, 6.07 \%$ and $3.96 \%$, respectively. 
Table 3 Effects of the interaction of the straw returning method and potassium fertilizer dosage on the morphological indicators of maize stems in different ecological regions

\begin{tabular}{|c|c|c|c|c|c|c|c|}
\hline Ecological region & Straw returning method & Potassium fertilizer dosage & Plant height $(\mathrm{cm})$ & Ear height $(\mathrm{cm})$ & Ear height coefficient & Stem meter(mm) & Stem length $(\mathrm{cm})$ \\
\hline \multirow{7}{*}{$\begin{array}{l}\text { Tumochuan Plain } \\
\text { irrigation area }\end{array}$} & \multirow{2}{*}{ ST } & $6 \mathrm{~K}$ & $329.72 \pm 3.82 \mathrm{a}$ & $128.17 \pm 2.33 \mathrm{a}$ & $0.39 \pm 0.01 \mathrm{a}$ & $27.58 \pm 1.15 \mathrm{a}$ & $14.40 \pm 0.11 \mathrm{a}$ \\
\hline & & $0 \mathrm{~K}$ & $306.03 \pm 3.87 \mathrm{c}$ & $118.29 \pm 2.34 \mathrm{c}$ & $0.39 \pm 0.01 \mathrm{a}$ & $25.41 \pm 1.16 \mathrm{c}$ & $12.95 \pm 0.13 \mathrm{c}$ \\
\hline & \multirow{2}{*}{ NST } & $6 \mathrm{~K}$ & $318.10 \pm 4.69 \mathrm{~b}$ & $124.43 \pm 2.43 \mathrm{~b}$ & $0.39 \pm 0.01 \mathrm{a}$ & $26.01 \pm 0.85 \mathrm{~b}$ & $13.16 \pm 0.10 \mathrm{~b}$ \\
\hline & & $0 \mathrm{~K}$ & $303.17 \pm 3.73 \mathrm{~d}$ & $118.23 \pm 3.01 \mathrm{c}$ & $0.39 \pm 0.01 \mathrm{a}$ & $24.98 \pm 0.91 \mathrm{~d}$ & $12.28 \pm 0.24 \mathrm{~d}$ \\
\hline & \multicolumn{2}{|c|}{ Under ST, the percentage increase of $6 \mathrm{~K}$ compared to $0 \mathrm{~K} \%$} & 7.74 & 8.36 & 0.57 & 8.57 & 11.24 \\
\hline & \multicolumn{2}{|c|}{ Under NST, the percentage increase of $6 \mathrm{~K}$ compared to $0 \mathrm{~K} \%$} & 4.92 & 5.25 & 0.31 & 4.14 & 7.21 \\
\hline & \multicolumn{2}{|c|}{ ST increases the percentage of K effectiveness $\%$} & 2.82 & 3.11 & 0.26 & 4.43 & 4.03 \\
\hline \multirow{7}{*}{$\begin{array}{l}\text { Hetao Plain } \\
\text { irrigation area }\end{array}$} & \multirow{2}{*}{ ST } & $6 \mathrm{~K}$ & $340.63 \pm 2.28 \mathrm{a}$ & $133.59 \pm 2.71 \mathrm{a}$ & $0.39 \pm 0.01 \mathrm{a}$ & $29.75 \pm 0.84 \mathrm{a}$ & $14.63 \pm 0.13 \mathrm{a}$ \\
\hline & & $0 \mathrm{~K}$ & $309.84 \pm 2.63 \mathrm{c}$ & $120.73 \pm 2.13 \mathrm{c}$ & $0.39 \pm 0.01 \mathrm{a}$ & $27.12 \pm 0.96 \mathrm{c}$ & $13.06 \pm 0.14 \mathrm{c}$ \\
\hline & \multirow{2}{*}{ NST } & $6 \mathrm{~K}$ & $318.14 \pm 4.35 \mathrm{~b}$ & $125.61 \pm 2.09 \mathrm{~b}$ & $0.39 \pm 0.01 \mathrm{a}$ & $27.80 \pm 0.86 \mathrm{~b}$ & $13.77 \pm 0.18 \mathrm{~b}$ \\
\hline & & $0 \mathrm{~K}$ & $303.81 \pm 4.68 \mathrm{~d}$ & $119.91 \pm 1.76 \mathrm{c}$ & $0.39 \pm 0.01 \mathrm{a}$ & $26.38 \pm 1.11 \mathrm{~d}$ & $12.68 \pm 0.19 \mathrm{~d}$ \\
\hline & \multicolumn{2}{|c|}{ Under ST, the percentage increase of $6 \mathrm{~K}$ compared to $0 \mathrm{~K} \%$} & 9.94 & 10.65 & 0.64 & 9.74 & 12.03 \\
\hline & \multicolumn{2}{|c|}{ Under NST, the percentage increase of $6 \mathrm{~K}$ compared to $0 \mathrm{~K} \%$} & 4.72 & 4.75 & 0.03 & 5.39 & 8.62 \\
\hline & \multicolumn{2}{|c|}{ ST increases the percentage of $\mathrm{K}$ effectiveness $\%$} & 5.22 & 5.90 & 0.62 & 4.35 & 3.41 \\
\hline \multirow{7}{*}{$\begin{array}{l}\text { Lingnan warm dry } \\
\text { zone }\end{array}$} & \multirow{2}{*}{ ST } & $6 \mathrm{~K}$ & $325.24 \pm 2.57 \mathrm{a}$ & $126.27 \pm 3.02 \mathrm{a}$ & $0.39 \pm 0.01 \mathrm{a}$ & $26.61 \pm 1.05 \mathrm{a}$ & $14.35 \pm 0.11 \mathrm{a}$ \\
\hline & & $0 \mathrm{~K}$ & $301.11 \pm 3.81 \mathrm{c}$ & $116.08 \pm 2.75 \mathrm{c}$ & $0.39 \pm 0.01 \mathrm{a}$ & $24.32 \pm 0.95 \mathrm{c}$ & $12.84 \pm 0.13 \mathrm{c}$ \\
\hline & \multirow{2}{*}{ NST } & $6 \mathrm{~K}$ & $310.95 \pm 4.11 \mathrm{~b}$ & $120.47 \pm 1.29 \mathrm{~b}$ & $0.39 \pm 0.00 \mathrm{a}$ & $24.77 \pm 0.74 \mathrm{~b}$ & $13.13 \pm 0.06 \mathrm{~b}$ \\
\hline & & $0 \mathrm{~K}$ & $297.62 \pm 3.98 \mathrm{~d}$ & $114.85 \pm 1.44 \mathrm{c}$ & $0.39 \pm 0.00 \mathrm{a}$ & $23.96 \pm 0.70 \mathrm{~d}$ & $12.18 \pm 0.11 \mathrm{~d}$ \\
\hline & \multicolumn{2}{|c|}{ Under ST, the percentage increase of $6 \mathrm{~K}$ compared to $0 \mathrm{~K} \%$} & 8.02 & 8.78 & 0.71 & 9.42 & 11.76 \\
\hline & \multicolumn{2}{|c|}{ Under NST, the percentage increase of $6 \mathrm{~K}$ compared to $0 \mathrm{~K} \%$} & 4.48 & 4.90 & 0.40 & 3.36 & 7.80 \\
\hline & \multicolumn{2}{|c|}{ ST increases the percentage of K effectiveness $\%$} & 3.54 & 3.88 & 0.31 & 6.07 & 3.96 \\
\hline
\end{tabular}

Note: These values in the table are the mean squares (MS) of the ANOVA. Values followed by different letters in a column are significant among treatments at the $5 \%$ level. The same below. 


\section{Effects of straw returning with potassium fertilizer on the phenotypic traits of spring maize stems}

As shown in Table S2, the effects of variation of the straw returning method, potassium fertilizer dosage, and ecological region on the stem fresh weight, stem dry weight, water content of maize grain and brix of stems reached an extremely significant level. The effects of the interaction of the straw returning method and potassium fertilizer dosage on the stem fresh weight, stem dry weight, water content of maize grain and brix of stems reached a significant or extremely significant level. The effects of the interaction of the straw returning method and ecological region and the interaction of the potassium fertilizer dosage and ecological region on the stem fresh weight, stem dry weight and water content of stems reached a significant or extremely significant level. The effect of the interaction of the straw returning method, potassium fertilizer dosage and ecological region on the stem fresh weight reached a significant level.

Table S2 ANOVA results for maize stem phenotypic traits under different straw returning methods and potassium fertilizer treatments

\begin{tabular}{ccccc}
\hline Source of variation & Fresh weight $(\mathrm{g})$ & Dry weight $(\mathrm{g})$ & Water content $(\%)$ & Brix (\%) \\
\hline Straw returning method (S) & $14527.75^{* *}$ & $348.73^{* *}$ & $29.58^{* *}$ & $13.47^{* *}$ \\
Potassium fertilizer dosage (K) & $63058.85^{* *}$ & $2000.00^{* *}$ & $92.83^{* *}$ & $25.10^{* *}$ \\
Ecological region (E) & $1904.81^{* *}$ & $195.57^{* *}$ & $2.95^{* *}$ & $0.37^{* *}$ \\
$\mathrm{~S} \times \mathrm{K}$ & $5014.01^{* *}$ & $126.12^{* *}$ & $3.85^{*}$ & $1.12^{* *}$ \\
$\mathrm{~S} \times \mathrm{E}$ & $447.20^{* *}$ & $13.92^{* *}$ & $0.55^{*}$ & $\mathrm{~ns}$ \\
$\mathrm{~K} \times \mathrm{E}$ & $187.82^{* *}$ & $7.51^{*}$ & $3.32^{*}$ & $0.02 \mathrm{~ns}$ \\
$\mathrm{~S} \times \mathrm{K} \times \mathrm{E}$ & $68.55^{*}$ & $1.59 \mathrm{~ns}$ & $0.04 \mathrm{~ns}$ & $\mathrm{~ns}$ \\
\hline
\end{tabular}

As shown in Table 4, the maize stem fresh weight, stem dry weight, water content of stems and brix of stems differed among the treatments. In the Tumochuan Plain irrigation area, under the straw returning treatment, the maize stem fresh weight, stem dry weight, water content of stems and brix of stems increased by $44.20 \%, 29.98 \%, 3.66 \%$, and $15.32 \%$, respectively, with potassium application in comparison with no potassium application. With no straw returning treatment, the maize stem fresh weight, stem dry weight, water content of stems and brix of stems increased by $28.22 \%, 21.09 \%$, $2.11 \%$, and $10.98 \%$, respectively, with potassium application in comparison with no potassium application. Straw returning increased the effectiveness of potassium application on the maize stem 
fresh weight, dry weight, water content and brix of stems by $15.98 \%, 8.89 \%, 1.55 \%$ and $4.35 \%$, respectively.

In the Hetao Plain irrigation area, under the straw returning treatment, the maize stem fresh weight, stem dry weight, water content and brix of stems increased by $45.41 \%, 24.88 \%, 5.51 \%$, and $13.82 \%$, respectively, with potassium application in comparison with no potassium application. With no straw returning treatment, the maize stem fresh weight, stem dry weight, water content and brix of stems increased by $25.63 \%, 13.22 \%, 4.10 \%$, and $9.38 \%$, respectively, with potassium application in comparison with no potassium application. Straw returning increased the effectiveness of potassium application on the maize stem fresh weight, stem dry weight, water content and brix of stems by $19.78 \%, 11.65 \%, 1.42 \%$, and $4.44 \%$, respectively.

In the Lingnan warm dry zone, under the straw returning treatment, the maize stem fresh weight, stem dry weight, water content and brix of stems increased by $40.09 \%, 27.82 \%, 3.22 \%$, and $14.51 \%$, respectively, with potassium application in comparison with no potassium application. With no straw returning treatment, the maize stem fresh weight, stem dry weight, water content and brix of stems were increased by $24.13 \%, 17.28 \%, 2.13 \%$, and $10.02 \%$, respectively, with potassium application in comparison with no potassium application. Straw returning increased the effectiveness of potassium application on the maize stem fresh weight, stem dry weight, water content and brix of stems by $15.96 \%, 10.55 \%, 1.09 \%$, and $4.50 \%$, respectively. 
Table 4 Effects of the interaction of the straw returning method and potassium fertilizer dosage on the phenotypic traits of maize stems in different ecological regions

\begin{tabular}{|c|c|c|c|c|c|c|}
\hline Ecological region & Straw returning method & Potassium fertilizer dosage & Fresh weight $(\mathrm{g})$ & Dry weight (g) & Water content $(\%)$ & Brix $(\%)$ \\
\hline \multirow{7}{*}{$\begin{array}{c}\text { Tumochuan Plain } \\
\text { irrigation area }\end{array}$} & \multirow{2}{*}{ ST } & $6 \mathrm{~K}$ & $273.16 \pm 3.01 \mathrm{a}$ & $66.73 \pm 2.77 \mathrm{a}$ & $75.57 \pm 0.99 \mathrm{a}$ & $12.37 \pm 0.20 \mathrm{a}$ \\
\hline & & $0 \mathrm{~K}$ & $189.44 \pm 2.82 \mathrm{c}$ & $51.33 \pm 1.58 \mathrm{c}$ & $72.90 \pm 0.88 \mathrm{c}$ & $10.73 \pm 0.11 \mathrm{c}$ \\
\hline & \multirow{2}{*}{ NST } & $6 \mathrm{~K}$ & $230.17 \pm 3.67 b$ & $60.23 \pm 2.18 b$ & $73.82 \pm 1.31 \mathrm{~b}$ & $11.15 \pm 0.26 \mathrm{~b}$ \\
\hline & & $0 \mathrm{~K}$ & $179.52 \pm 1.59 \mathrm{~d}$ & $49.74 \pm 1.86 \mathrm{~d}$ & $72.29 \pm 0.98 \mathrm{~d}$ & $10.05 \pm 0.12 \mathrm{c}$ \\
\hline & \multicolumn{2}{|c|}{ Under ST, the percentage increase of $6 \mathrm{~K}$ compared to $0 \mathrm{~K} \%$} & 44.20 & 29.98 & 3.66 & 15.32 \\
\hline & \multicolumn{2}{|c|}{ Under NST, the percentage increase of $6 \mathrm{~K}$ compared to $0 \mathrm{~K} \%$} & 28.22 & 21.09 & 2.11 & 10.98 \\
\hline & \multicolumn{2}{|c|}{ ST increases the percentage of $\mathrm{K}$ effectiveness \% } & 15.98 & 8.89 & 1.55 & 4.35 \\
\hline \multirow{7}{*}{$\begin{array}{c}\text { Hetao Plain irrigation } \\
\text { area }\end{array}$} & \multirow{2}{*}{ ST } & $6 \mathrm{~K}$ & $294.74 \pm 4.82 \mathrm{a}$ & $71.17 \pm 3.27 \mathrm{a}$ & $75.85 \pm 1.07 \mathrm{a}$ & $12.44 \pm 0.12 \mathrm{a}$ \\
\hline & & $0 \mathrm{~K}$ & $202.76 \pm 4.89 \mathrm{c}$ & $56.98 \pm 1.65 \mathrm{c}$ & $71.89 \pm 0.78 \mathrm{c}$ & $10.93 \pm 0.16 \mathrm{c}$ \\
\hline & \multirow{2}{*}{ NST } & $6 \mathrm{~K}$ & $230.20 \pm 7.43 b$ & $60.89 \pm 2.11 \mathrm{~b}$ & $73.53 \pm 1.07 \mathrm{~b}$ & $11.25 \pm 0.06 \mathrm{~b}$ \\
\hline & & $0 \mathrm{~K}$ & $183.29 \pm 3.06 \mathrm{~d}$ & $53.78 \pm 1.70 \mathrm{~d}$ & $70.64 \pm 1.28 \mathrm{~d}$ & $10.29 \pm 0.11 \mathrm{c}$ \\
\hline & \multicolumn{2}{|c|}{ Under ST, the percentage increase of $6 \mathrm{~K}$ compared to $0 \mathrm{~K} \%$} & 45.41 & 24.88 & 5.51 & 13.82 \\
\hline & \multicolumn{2}{|c|}{ Under NST, the percentage increase of $6 \mathrm{~K}$ compared to $0 \mathrm{~K} \%$} & 25.63 & 13.23 & 4.10 & 9.38 \\
\hline & \multicolumn{2}{|c|}{ ST increases the percentage of $K$ effectiveness $\%$} & 19.78 & 11.65 & 1.42 & 4.44 \\
\hline \multirow{7}{*}{ Lingnan warm dry zone } & \multirow{2}{*}{ ST } & $6 \mathrm{~K}$ & $257.51 \pm 3.52 \mathrm{a}$ & $63.21 \pm 2.11 \mathrm{a}$ & $75.44 \pm 1.10 \mathrm{a}$ & $12.22 \pm 0.13 \mathrm{a}$ \\
\hline & & $0 \mathrm{~K}$ & $183.85 \pm 3.76 \mathrm{c}$ & $49.45 \pm 1.64 \mathrm{c}$ & $73.09 \pm 1.12 \mathrm{c}$ & $10.67 \pm 0.17 \mathrm{c}$ \\
\hline & \multirow{2}{*}{ NST } & $6 \mathrm{~K}$ & $216.83 \pm 3.52 \mathrm{~b}$ & $56.82 \pm 1.15 b$ & $73.79 \pm 0.95 b$ & $10.97 \pm 0.09 b$ \\
\hline & & $0 \mathrm{~K}$ & $174.73 \pm 2.71 \mathrm{~d}$ & $48.48 \pm 1.83 \mathrm{~d}$ & $72.25 \pm 1.02 \mathrm{~d}$ & $9.97 \pm 0.07 \mathrm{~d}$ \\
\hline & \multicolumn{2}{|c|}{ Under ST, the percentage increase of $6 \mathrm{~K}$ compared to $0 \mathrm{~K} \%$} & 40.09 & 27.82 & 3.22 & 14.51 \\
\hline & \multicolumn{2}{|c|}{ Under NST, the percentage increase of $6 \mathrm{~K}$ compared to $0 \mathrm{~K} \%$} & 24.13 & 17.28 & 2.13 & 10.02 \\
\hline & \multicolumn{2}{|c|}{ ST increases the percentage of K effectiveness $\%$} & 15.96 & 10.55 & 1.09 & 4.50 \\
\hline
\end{tabular}


Effects of the straw returning method and potassium fertilizer dosage on the lodging resistance mechanical properties of spring maize stems

As shown in Table S3, the effects of the single factor, two-factor interactions and three-factor interactions of the straw returning method, potassium fertilizer dosage, and ecological region on the maize stem puncture strength, compressive strength and bending strength were extremely significant.

Table S3 ANOVA results for maize stem lodging resistance mechanical properties under different straw returning methods and potassium fertilizer treatments

\begin{tabular}{|c|c|c|c|}
\hline Source of variation & $\begin{array}{l}\text { Puncture strength } \\
\qquad\left(\mathrm{N} / \mathrm{mm}^{2}\right)\end{array}$ & $\begin{array}{c}\text { Compressive strength } \\
\qquad\left(\mathrm{N} / \mathrm{mm}^{2}\right)\end{array}$ & $\begin{array}{c}\text { Bending strength } \\
\left(\mathrm{N} / \mathrm{mm}^{2}\right)\end{array}$ \\
\hline Straw returning method (S) & $707.20 * *$ & $16821.02 * *$ & $42263.89 * *$ \\
\hline Potassium fertilizer dosage $(\mathrm{K})$ & $1652.81^{* *}$ & $38373.02 * *$ & $69126.95 * *$ \\
\hline Ecological region $(\mathrm{E})$ & $63.24 * *$ & $1708.52 * *$ & $364.42 * *$ \\
\hline $\mathrm{S} \times \mathrm{K}$ & $200.90^{* *}$ & $3733.86^{* *}$ & $7359.13 * *$ \\
\hline $\mathrm{S} \times \mathrm{E}$ & $26.08 * *$ & $248.20 * *$ & $77.73^{* *}$ \\
\hline $\mathrm{K} \times \mathrm{E}$ & $6.27 * *$ & $110.27 * *$ & $109.37 * *$ \\
\hline $\mathrm{S} \times \mathrm{K} \times \mathrm{E}$ & $5.89 * *$ & $109.60 * *$ & $77.75^{* *}$ \\
\hline
\end{tabular}

As shown in Figure 1 and Table S4, the maize stem puncture strength, stem bending strength and stem compressive strength varied widely between the treatments. When straw returning with no potassium application was compared to straw returning with potassium application in the Tumochuan Plain irrigation area, Hetao Plain irrigation area, and Lingnan warm dry zone, the treatment with potassium increased the stem puncture strength by $22.06 \%, 26.73 \%$, and $21.17 \%$, respectively, whereas the stem compressive strength was increased by $20.72 \%, 24.14 \%$, and $20.83 \%$, respectively, and the stem bending strength was increased by $28.82 \%, 32.56 \%$, and $27.44 \%$, respectively. With no straw returning treatment, the stem puncture strength in the Tumochuan Plain irrigation area, Hetao Plain irrigation area, and Lingnan warm dry zone was increased by $11.51 \%, 11.91 \%$, and $12.28 \%$, respectively, with potassium application in comparison with no potassium application, whereas the stem compressive strength was increased by $9.99 \%, 12.37 \%$, and $14.36 \%$, respectively, and the stem bending strength was increased by $16.81 \%, 16.87 \%$, and $16.55 \%$, respectively. In the Tumochuan Plain irrigation area, straw returning increased the effectiveness of potassium application on the stem puncture strength, stem compressive strength and stem bending strength by $10.55 \%, 14.82 \%$, and 

made available under aCC-BY 4.0 International license.

$8.89 \%$, respectively. In the Hetao Plain irrigation area, straw returning increased the effectiveness of potassium application on the stem puncture strength, stem compressive strength and stem bending strength by $10.73 \%, 11.76 \%$, and $6.47 \%$, respectively. In the Lingnan warm dry zone, straw returning increased the effectiveness of potassium application on the stem puncture strength, stem compressive strength and stem bending strength by $12.01 \%, 15.69 \%$, and $10.89 \%$, respectively.

Figure 1 Stem lodging resistance mechanical properties of spring maize under different straw returning methods and potassium fertilizer treatments 
Table S4 Effects of the interaction of the straw returning method and potassium fertilizer dosage on the lodging resistance mechanical properties of maize stems in different

\begin{tabular}{|c|c|c|c|c|c|}
\hline Ecological region & Straw returning method & Potassium fertilizer dosage & Puncture strength $\left(\mathrm{N} / \mathrm{mm}^{2}\right)$ & Compressive strength $\left(\mathrm{N} / \mathrm{mm}^{2}\right)$ & Bending strength $\left(\mathrm{N} / \mathrm{mm}^{2}\right)$ \\
\hline \multirow{7}{*}{$\begin{array}{l}\text { Tumochuan Plain } \\
\text { irrigation area }\end{array}$} & \multirow{2}{*}{ ST } & $6 \mathrm{~K}$ & $74.55 \pm 3.31 \mathrm{a}$ & $368.84 \pm 10.63 \mathrm{a}$ & $390.83 \pm 7.28 \mathrm{a}$ \\
\hline & & $0 \mathrm{~K}$ & $61.06 \pm 1.56 \mathrm{c}$ & $305.53 \pm 6.83 \mathrm{c}$ & $303.42 \pm 7.24 \mathrm{c}$ \\
\hline & \multirow{2}{*}{ NST } & $6 \mathrm{~K}$ & $63.80 \pm 3.06 \mathrm{~b}$ & $316.83 \pm 5.56 \mathrm{~b}$ & $319.63 \pm 6.18 b$ \\
\hline & & $0 \mathrm{~K}$ & $57.21 \pm 1.57 \mathrm{~d}$ & $288.08 \pm 5.68 \mathrm{~d}$ & $273.67 \pm 7.40 \mathrm{~d}$ \\
\hline & \multicolumn{2}{|c|}{ Under ST, the percentage increase of $6 \mathrm{~K}$ compared to $0 \mathrm{~K} \%$} & 22.06 & 20.72 & 28.82 \\
\hline & \multicolumn{2}{|c|}{ Under NST, the percentage increase of $6 \mathrm{~K}$ compared to $0 \mathrm{~K} \%$} & 11.51 & 9.99 & 16.81 \\
\hline & \multicolumn{2}{|c|}{ ST increases the percentage of $\mathrm{K}$ effectiveness $\%$} & 10.55 & 10.73 & 12.01 \\
\hline \multirow{7}{*}{$\begin{array}{l}\text { Hetao Plain } \\
\text { irrigation area }\end{array}$} & \multirow{2}{*}{ ST } & $6 \mathrm{~K}$ & $78.78 \pm 1.79 \mathrm{a}$ & $385.52 \pm 6.70 \mathrm{a}$ & $406.06 \pm 5.76 \mathrm{a}$ \\
\hline & & $0 \mathrm{~K}$ & $62.17 \pm 1.79 \mathrm{c}$ & $310.59 \pm 6.80 \mathrm{c}$ & $306.41 \pm 7.68 \mathrm{c}$ \\
\hline & \multirow{2}{*}{ NST } & $6 \mathrm{~K}$ & $65.04 \pm 2.84 \mathrm{~b}$ & $326.17 \pm 7.18 b$ & $321.84 \pm 6.36 \mathrm{~b}$ \\
\hline & & $0 \mathrm{~K}$ & $58.10 \pm 1.97 \mathrm{~d}$ & $290.28 \pm 7.36 \mathrm{~d}$ & $275.40 \pm 5.37 \mathrm{~d}$ \\
\hline & \multicolumn{2}{|c|}{ Under ST, the percentage increase of $6 \mathrm{~K}$ compared to $0 \mathrm{~K} \%$} & 26.73 & 24.14 & 32.56 \\
\hline & \multicolumn{2}{|c|}{ Under NST, the percentage increase of $6 \mathrm{~K}$ compared to $0 \mathrm{~K} \%$} & 11.91 & 12.37 & 16.87 \\
\hline & \multicolumn{2}{|c|}{ ST increases the percentage of $K$ effectiveness $\%$} & 14.82 & 11.76 & 15.69 \\
\hline \multirow{7}{*}{$\begin{array}{l}\text { Lingnan warm dry } \\
\text { zone }\end{array}$} & \multirow{2}{*}{ ST } & $6 \mathrm{~K}$ & $70.85 \pm 2.31 \mathrm{a}$ & $353.05 \pm 7.53 \mathrm{a}$ & $386.13 \pm 4.82 \mathrm{a}$ \\
\hline & & $0 \mathrm{~K}$ & $58.48 \pm 2.09 \mathrm{c}$ & $292.22 \pm 7.71 \mathrm{c}$ & $303.09 \pm 7.89 \mathrm{c}$ \\
\hline & \multirow{2}{*}{ NST } & $6 \mathrm{~K}$ & $63.76 \pm 2.09 \mathrm{~b}$ & $316 . .62 \pm 5.92 \mathrm{~b}$ & $315.86 \pm 5.15 b$ \\
\hline & & $0 \mathrm{~K}$ & $56.78 \pm 1.48 \mathrm{~d}$ & $276.85 \pm 3.19 \mathrm{~d}$ & $271.05 \pm 6.60 \mathrm{~d}$ \\
\hline & \multicolumn{2}{|c|}{ Under ST, the percentage increase of $6 \mathrm{~K}$ compared to $0 \mathrm{~K} \%$} & 21.17 & 20.83 & 27.44 \\
\hline & \multicolumn{2}{|c|}{ Under NST, the percentage increase of $6 \mathrm{~K}$ compared to $0 \mathrm{~K} \%$} & 12.28 & 14.36 & 16.55 \\
\hline & \multicolumn{2}{|c|}{ ST increases the percentage of $\mathrm{K}$ effectiveness $\%$} & 8.89 & 6.47 & 10.89 \\
\hline
\end{tabular}




\section{Effects of the straw returning method and potassium fertilizer dosage on maize grain quality}

As shown in Table S5, the effects of variation of the straw returning method, potassium fertilizer dosage, and ecological region on the protein content, starch content, crude fat content and water content of grains all reached an extremely significant level. The effects of the interaction of the straw returning method and potassium fertilizer dosage and the interaction of the potassium fertilizer dosage and ecological region on the indicators mentioned above reached an extremely significant level. The effects of the interaction of the straw returning method and ecological region on the protein content, starch content, and crude fat content of maize grains reached extremely significant levels. The effect of the interaction of the straw returning method, potassium fertilizer dosage and ecological region on the water content of grains was significant.

Table S5 ANOVA results for maize grain quality under different straw returning methods and potassium fertilizer treatments

\begin{tabular}{ccccc}
\hline Source of variation & $\begin{array}{c}\text { Protein content of } \\
\text { grains (\%) }\end{array}$ & $\begin{array}{c}\text { Starch content of } \\
\text { grains (\%) }\end{array}$ & $\begin{array}{c}\text { Crude fat content of } \\
\text { grains (\%) }\end{array}$ & $\begin{array}{c}\text { Water content of } \\
\text { grains (\%) }\end{array}$ \\
\hline Straw returning method (S) & $2.66^{* *}$ & $2.56^{* *}$ & $0.73^{* *}$ & $1.24^{* *}$ \\
Potassium fertilizer dosage (K) & $12.51^{* *}$ & $12.05^{* *}$ & $3.07^{* *}$ & $4.19^{* *}$ \\
Ecological region (E) & $2.65^{* *}$ & $17.78^{* *}$ & $0.74^{* *}$ & $0.89^{* *}$ \\
$\mathrm{~S} \times \mathrm{K}$ & $0.68^{* *}$ & $0.25^{* *}$ & $0.06^{* *}$ & $0.55^{* *}$ \\
$\mathrm{~S} \times \mathrm{E}$ & $0.08^{* *}$ & $0.09^{* *}$ & $0.01^{* *}$ & $0.01 \mathrm{~ns}$ \\
$\mathrm{~K} \times \mathrm{E}$ & $0.09^{* *}$ & $0.09^{* *}$ & $0.01^{* *}$ & $0.04^{* *}$ \\
$\mathrm{~S} \times \mathrm{K} \times \mathrm{E}$ & $0.02 \mathrm{~ns}$ & $\mathrm{~ns}$ & $\mathrm{~ns}$ & $0.01^{*}$ \\
\hline
\end{tabular}

As shown in Figure 2 and Table S6, the protein content, starch content, crude fat content and water content of maize grains differed significantly among the treatments. In the Tumochuan Plain irrigation area, Hetao Plain irrigation area, and Lingnan warm dry zone, straw returning treatment increased the protein content of grains by $11.78 \%, 13.68 \%$, and $13.53 \%$, respectively, with potassium application in comparison with no potassium application, whereas the starch content of grains increased by $1.34 \%$, $1.68 \%$, and $1.31 \%$, while the crude fat content of grains increased by $12.71 \%, 14.72 \%$, and $14.73 \%$, and the water content of grains decreased by $7.30 \%, 7.22 \%$, and $7.66 \%$. With no straw returning treatment, the protein content of grains in the Tumochuan Plain irrigation area, Hetao Plain irrigation area, and Lingnan warm dry zone increased by $7.52 \%, 10.19 \%$, and $7.03 \%$, respectively, with potassium 
application in comparison with no potassium application, whereas the starch content of grains increased by $1.01 \%, 1.25 \%$, and $0.99 \%$, while the crude fat content of grains increased by $10.21 \%, 12.62 \%$, and $10.30 \%$, and the water content of grains decreased by $2.63 \%, 2.67 \%$, and $4.91 \%$. In the Tumochuan Plain irrigation area, Hetao Plain irrigation area, and Lingnan warm dry zone, straw returning increased the effectiveness of potassium application on the protein content of grains by $4.26 \%, 3.49 \%$, and $6.50 \%$, respectively, whereas its effectiveness on the starch content of grains increased by $0.33 \%, 0.43 \%$, and $0.32 \%$, while its effectiveness on the crude fat content of grains increased by $2.51 \%, 2.09 \%$, and $4.43 \%$, and its effectiveness on the water content of grains increased by $4.67 \%, 4.55 \%$, and $2.75 \%$.

Figure 2 Grain quality of spring maize under different straw returning methods and potassium fertilizer treatments 
$\underline{\text { Table S6 Effects of the interaction of the straw returning method and potassium fertilizer dosage on maize grain quality in different ecological regions }}$

\begin{tabular}{|c|c|c|c|c|c|c|}
\hline Ecological region & Straw returning method & Potassium fertilizer dosage & $\begin{array}{c}\text { Protein content of } \\
\text { grains (\%) }\end{array}$ & $\begin{array}{c}\text { Starch content of } \\
\text { grains }(\%)\end{array}$ & $\begin{array}{c}\text { Crude fat content of } \\
\text { grains }(\%)\end{array}$ & $\begin{array}{c}\text { Water content of } \\
\text { grains }(\%)\end{array}$ \\
\hline \multirow{7}{*}{$\begin{array}{c}\text { Tumochuan Plain } \\
\text { irrigation area }\end{array}$} & \multirow[b]{2}{*}{ ST } & $6 \mathrm{~K}$ & $9.59 \pm 0.21 \mathrm{a}$ & $71.45 \pm 1.24 \mathrm{a}$ & $4.18 \pm 0.04 \mathrm{a}$ & $9.02 \pm 0.16 \mathrm{~d}$ \\
\hline & & $0 \mathrm{~K}$ & $8.58 \pm 0.22 \mathrm{c}$ & $70.51 \pm 1.18 \mathrm{c}$ & $3.71 \pm 0.09 \mathrm{c}$ & $9.73 \pm 0.19 b$ \\
\hline & \multirow{2}{*}{ NST } & $6 \mathrm{~K}$ & $9.07 \pm 0.19 \mathrm{~b}$ & $70.99 \pm 1.41 \mathrm{~b}$ & $3.90 \pm 0.11 \mathrm{~b}$ & $9.55 \pm 0.18 \mathrm{c}$ \\
\hline & & $0 \mathrm{~K}$ & $8.44 \pm 0.20 \mathrm{~d}$ & $70.28 \pm 1.43 \mathrm{~d}$ & $3.54 \pm 0.13 \mathrm{~d}$ & $9.81 \pm 0.21 \mathrm{a}$ \\
\hline & \multicolumn{2}{|c|}{ Under ST, the percentage increase of $6 \mathrm{~K}$ compared to $0 \mathrm{~K} \%$} & 11.78 & 1.34 & 12.71 & 7.30 \\
\hline & \multicolumn{2}{|c|}{ Under NST, the percentage increase of $6 \mathrm{~K}$ compared to $0 \mathrm{~K} \%$} & 7.52 & 1.01 & 10.21 & 2.63 \\
\hline & \multicolumn{2}{|c|}{ ST increases the percentage of K effectiveness \% } & 4.26 & 0.33 & 2.51 & 4.67 \\
\hline \multirow{7}{*}{$\begin{array}{l}\text { Hetao Plain } \\
\text { irrigation area }\end{array}$} & \multirow{2}{*}{ ST } & $6 \mathrm{~K}$ & $10.22 \pm 0.26 \mathrm{a}$ & $73.13 \pm 1.24 \mathrm{a}$ & $4.38 \pm 0.06 \mathrm{a}$ & $8.82 \pm 0.17 \mathrm{~d}$ \\
\hline & & $0 \mathrm{~K}$ & $8.99 \pm 0.17 \mathrm{c}$ & $71.92 \pm 1.18 \mathrm{c}$ & $3.82 \pm 0.04 \mathrm{c}$ & $9.50 \pm 0.15 b$ \\
\hline & \multirow{2}{*}{ NST } & $6 \mathrm{~K}$ & $9.69 \pm 0.18 \mathrm{~b}$ & $72.65 \pm 1.22 \mathrm{~b}$ & $4.16 \pm 0.08 \mathrm{~b}$ & $9.35 \pm .0 .15 \mathrm{c}$ \\
\hline & & $0 \mathrm{~K}$ & $8.79 \pm 0.08 \mathrm{~d}$ & $71.75 \pm 1.17 \mathrm{~d}$ & $3.70 \pm 0.10 \mathrm{~d}$ & $9.60 \pm 0.18 \mathrm{a}$ \\
\hline & \multicolumn{2}{|c|}{ Under ST, the percentage increase of $6 \mathrm{~K}$ compared to $0 \mathrm{~K} \%$} & 13.68 & 1.68 & 14.72 & 7.22 \\
\hline & \multicolumn{2}{|c|}{ Under NST, the percentage increase of $6 \mathrm{~K}$ compared to $0 \mathrm{~K} \%$} & 10.19 & 1.25 & 12.62 & 2.67 \\
\hline & \multicolumn{2}{|c|}{ ST increases the percentage of K effectiveness \% } & 3.49 & 0.43 & 2.09 & 4.55 \\
\hline \multirow{7}{*}{$\begin{array}{c}\text { Lingnan warm dry } \\
\text { zone }\end{array}$} & \multirow{2}{*}{ ST } & $6 \mathrm{~K}$ & $9.57 \pm 0.12 \mathrm{a}$ & $71.40 \pm 1.22 \mathrm{a}$ & $4.02 \pm 0.07 \mathrm{a}$ & $9.23 \pm 0.17 \mathrm{~d}$ \\
\hline & & $0 \mathrm{~K}$ & $8.43 \pm 0.13 \mathrm{c}$ & $70.48 \pm 1.20 \mathrm{c}$ & $3.51 \pm 0.08 \mathrm{c}$ & $10.00 \pm 0.16 \mathrm{~b}$ \\
\hline & \multirow{2}{*}{ NST } & $6 \mathrm{~K}$ & $8.72 \pm 0.24 \mathrm{~b}$ & $70.72 \pm 1.22 \mathrm{~b}$ & $3.66 \pm 0.04 \mathrm{~b}$ & $9.61 \pm 0.25 \mathrm{c}$ \\
\hline & & $0 \mathrm{~K}$ & $8.15 \pm 0.32 \mathrm{~d}$ & $70.02 \pm 1.15 \mathrm{~d}$ & $3.32 \pm 0.05 \mathrm{~d}$ & $10.11 \pm 0.23 \mathrm{a}$ \\
\hline & \multicolumn{2}{|c|}{ Under ST, the percentage increase of $6 \mathrm{~K}$ compared to $0 \mathrm{~K} \%$} & 13.53 & 1.31 & 14.73 & 7.66 \\
\hline & \multicolumn{2}{|c|}{ Under NST, the percentage increase of $6 \mathrm{~K}$ compared to $0 \mathrm{~K} \%$} & 7.03 & 0.99 & 10.30 & 4.91 \\
\hline & \multicolumn{2}{|c|}{ ST increases the percentage of $\mathrm{K}$ effectiveness $\%$} & 6.50 & 0.32 & 4.43 & 2.75 \\
\hline
\end{tabular}


bioRxiv preprint doi: https://doi org/10.1101/2021.04 19.440424; this version posted April 19, 2021. The copyright holder for this preprint (which was not certified by peer review) is the author/funder, who has granted bioRxiv a license to display the preprint in perpetuity. It is made available under aCC-BY 4.0 International license.

\section{Effects of straw returning method and potassium fertilizer dosage on maize yield}

As shown in Table S7, the effects of the single factor, two-factor interaction and three-factor interactions

3 of the straw returning method, potassium fertilizer dosage, and ecological region on the maize grain number

4 per ear, 1000-grain weight, water content and yield all reached a significant or extremely significant level,

5 whereas their effects on ear number did not reach a significant level.

Table S7 ANOVA results for maize yield and yield component factors under different straw returning methods and potassium fertilizer treatments

\begin{tabular}{|c|c|c|c|c|c|}
\hline Source of variation & $\begin{array}{c}\text { Ears per } \\
\text { hectare } \\
\left(\text { fringe } / \mathrm{hm}^{2} \text { ) }\right.\end{array}$ & $\begin{array}{c}\text { Grains per spike } \\
\text { (grain/ fringe) }\end{array}$ & $\begin{array}{l}\text { 1000-seed } \\
\text { weight (g) }\end{array}$ & $\begin{array}{c}\text { Water } \\
\text { content } \\
(\%) \\
\end{array}$ & $\begin{array}{c}\text { Yield } \\
\left(\mathrm{kg} / \mathrm{hm}^{2}\right)\end{array}$ \\
\hline Straw returning method $(\mathrm{S})$ & $\mathrm{ns}$ & $2485.84^{* *}$ & $7117.71 * *$ & $1.54^{* *}$ & $21187480.00^{* *}$ \\
\hline Potassium fertilizer dosage (K) & $\mathrm{ns}$ & $9845.77 * *$ & $16246.02 * *$ & $3.93 * *$ & $56653950.00 * *$ \\
\hline Ecological region $(\mathrm{E})$ & ns & $1875.02 * *$ & $12030.89 * *$ & $0.27^{* *}$ & $25155970.00^{* *}$ \\
\hline $\mathrm{S} \times \mathrm{K}$ & ns & $733.60 * *$ & $1475.11 * *$ & $0.48^{* *}$ & $4589876.00^{* *}$ \\
\hline $\mathrm{S} \times \mathrm{E}$ & ns & $33.74 *$ & $337.56 * *$ & $0.03 * *$ & $1029908.00^{* *}$ \\
\hline $\mathrm{K} \times \mathrm{E}$ & $\mathrm{ns}$ & $60.24 * *$ & $113.48 * *$ & $0.03 * *$ & $644030.00^{* *}$ \\
\hline $\mathrm{S} \times \mathrm{K} \times \mathrm{E}$ & ns & $28.79 \mathrm{~ns}$ & $100.11 * *$ & $0.02 * *$ & $399520.00^{* *}$ \\
\hline
\end{tabular}

As shown in Table 5, the maize grain number per ear, 1000-grain weight, water content and yield were significantly different among the treatments. In the Tumochuan Plain irrigation area, Hetao Plain irrigation 11 area, and Lingnan warm dry zone, straw returning with potassium application increased the grain number per ear by $5.43 \%, 6.56 \%$, and $4.74 \%$, respectively, in comparison with no potassium application. With no straw 13 returning treatment, the grain number per ear increased by $3.27 \%, 3.33 \%$, and $3.04 \%$, respectively, with 14 potassium application in comparison with no potassium application. Straw returning increased the 15 effectiveness of potassium application on the grain number per ear by $2.15 \%, 3.22 \%$, and $1.69 \%$, respectively. Under the straw returning treatment, the maize 1000-grain weight in the Tumochuan Plain irrigation area, 17 Hetao Plain irrigation area, and Lingnan warm dry zone increased by $14.60 \%, 14.79 \%$, and $11.13 \%$, 18 respectively, with potassium application in comparison with no potassium application. With no straw 19 returning, the maize 1000 -grain weight increased by $8.18 \%, 6.82 \%$, and $7.83 \%$, respectively, with potassium application in comparison with no potassium application. Straw returning increased the effectiveness of 21 potassium application on the maize 1000 -grain weight by $6.42 \%, 7.97 \%$ and $3.29 \%$, respectively. 
bioRxiv preprint doi: https://doi org/10.1101/2021.04 19.440424; this version posted April 19, 2021. The copyright holder for this preprint (which was not certified by peer review) is the author/funder, who has granted bioRxiv a license to display the preprint in perpetuity. It is made available under aCC-BY 4.0 International license.

Under the straw returning treatment, the water content of grains in the Tumochuan Plain irrigation area,

23 Hetao Plain irrigation area, and Lingnan warm dry zone was reduced by $3.51 \%, 4.17 \%$, and $2.88 \%$,

24 respectively, with potassium application in comparison with no potassium application. With no straw

25 returning treatment, the water content of grains was reduced by $1.42 \%, 1.89 \%$, and $1.72 \%$, respectively, with

26 potassium application in comparison with no potassium application. Straw returning increased the

27 effectiveness of potassium application on the water content of grains by $2.09 \%, 2.27 \%$ and $1.15 \%$,

28 respectively.

29 Under the straw returning treatment, the maize yield in the Tumochuan Plain irrigation area, Hetao Plain

30 irrigation area, and Lingnan warm dry zone increased by $21.20 \%, 24.31 \%$, and $17.14 \%$, respectively, with

31 potassium application in comparison with no potassium application. With no straw returning treatment, the

maize yield increased by $13.20 \%, 11.81 \%$, and $12.27 \%$, respectively, with potassium application in

33 comparison with no potassium application. Straw returning increased the effectiveness of potassium

34 application on maize yield by $8.00 \%, 12.50 \%$, and $4.87 \%$, respectively.

Under the straw returning treatment, the maize yield variation coefficient in the Tumochuan Plain irrigation area, Hetao Plain irrigation area, and Lingnan warm dry zone was reduced by $13.98 \%, 16.39 \%$, and

$3716.53 \%$, respectively, with potassium application in comparison with no potassium application. With no straw returning treatment, the maize yield variation coefficient was reduced by $8.91 \%, 9.26 \%$, and $8.98 \%$,

39 respectively, with potassium application in comparison with no potassium application. Straw returning increased the effectiveness of potassium application on the maize yield variation coefficient by $5.07 \%, 7.13 \%$,

41 and $7.55 \%$, respectively. Straw returning improved the effectiveness of potassium application on the maize grain number per ear, 1000-grain weight, water content, yield and yield variation coefficient. 
Table 5 Maize yield and yield component factors under different straw returning methods and potassium fertilizer treatments

\begin{tabular}{|c|c|c|c|c|c|c|c|c|}
\hline $\begin{array}{c}\text { Ecological } \\
\text { region }\end{array}$ & Straw returning method & Potassium fertilizer dosage & $\begin{array}{c}\text { Spike } \\
\text { (fringes } / \mathrm{hm}^{2} \text { ) }\end{array}$ & $\begin{array}{c}\text { Grain number per } \\
\text { spike } \\
\text { (grains/fringe) }\end{array}$ & $\begin{array}{l}\text { 1000-grain } \\
\text { weight (g) }\end{array}$ & $\begin{array}{c}\text { Water content } \\
(\%)\end{array}$ & $\begin{array}{c}\text { Yield } \\
\left(\mathrm{kg} / \mathrm{hm}^{2}\right)\end{array}$ & $\begin{array}{l}\text { Variation } \\
\text { coefficient }\end{array}$ \\
\hline \multirow{7}{*}{$\begin{array}{c}\text { Tumochuan } \\
\text { Plain } \\
\text { irrigation } \\
\text { area }\end{array}$} & \multirow{2}{*}{ ST } & $6 \mathrm{~K}$ & $79473 \pm 814.81 \mathrm{a}$ & $615.48 \pm 15.29 \mathrm{a}$ & $357.90 \pm 14.12 \mathrm{a}$ & $18.97 \pm 0.40 \mathrm{~d}$ & $14181.86 \pm 608.93 \mathrm{a}$ & 4.29 \\
\hline & & $0 \mathrm{~K}$ & $79902 \pm 453.16 \mathrm{a}$ & $583.80 \pm 14.00 \mathrm{c}$ & $312.36 \pm 13.59 \mathrm{c}$ & $19.66 \pm 0.38 b$ & $11705.04 \pm 584.26 \mathrm{c}$ & 4.99 \\
\hline & \multirow{2}{*}{ NST } & $6 \mathrm{~K}$ & $80682 \pm 973.64 \mathrm{a}$ & $597.12 \pm 15.07 \mathrm{~b}$ & $328.50 \pm 11.41 \mathrm{~b}$ & $19.48 \pm 0.37 \mathrm{c}$ & $12746.54 \pm 665.25 \mathrm{~b}$ & 5.22 \\
\hline & & $0 \mathrm{~K}$ & $79920 \pm 1950.49 \mathrm{a}$ & $578.20 \pm 14.52 \mathrm{~d}$ & $303.76 \pm 13.01 \mathrm{~d}$ & $19.76 \pm 0.39 \mathrm{a}$ & $11263.54 \pm 645.34 \mathrm{~d}$ & 5.73 \\
\hline & \multicolumn{2}{|c|}{ Under ST, the percentage increase of $6 \mathrm{~K}$ compared to $0 \mathrm{~K} \%$} & & 5.43 & 14.60 & 3.51 & 21.20 & 13.98 \\
\hline & \multicolumn{2}{|c|}{ Under NST, the percentage increase of $6 \mathrm{~K}$ compared to $0 \mathrm{~K} \%$} & & 3.27 & 8.18 & 1.42 & 13.20 & 8.91 \\
\hline & \multicolumn{2}{|c|}{ ST increases the percentage of K effectiveness \% } & & 2.15 & 6.42 & 2.09 & 8.00 & 5.07 \\
\hline \multirow{7}{*}{$\begin{array}{c}\text { Hetao Plain } \\
\text { irrigation } \\
\text { area }\end{array}$} & \multirow{2}{*}{ ST } & $6 \mathrm{~K}$ & $79842 \pm 528.46 \mathrm{a}$ & $632.20 \pm 13.73 \mathrm{a}$ & $392.46 \pm 14.70 \mathrm{a}$ & $18.75 \pm 0.31 \mathrm{~d}$ & $16091.95 \pm 575.74 \mathrm{a}$ & 3.58 \\
\hline & & $0 \mathrm{~K}$ & $79359 \pm 986.05 \mathrm{a}$ & $593.32 \pm 14.46 \mathrm{c}$ & $342.18 \pm 18.76 \mathrm{c}$ & $19.56 \pm 0.41 \mathrm{~b}$ & $12949.52 \pm 554.12 \mathrm{c}$ & 4.28 \\
\hline & \multirow{2}{*}{ NST } & $6 \mathrm{~K}$ & $79566 \pm 671.79 \mathrm{a}$ & $606.76 \pm 14.87 \mathrm{~b}$ & $347.30 \pm 11.79 b$ & $19.37 \pm 0.37 \mathrm{c}$ & $13519.84 \pm 608.29 \mathrm{~b}$ & 4.50 \\
\hline & & $0 \mathrm{~K}$ & $78924 \pm 751.09 \mathrm{a}$ & $587.16 \pm 11.61 \mathrm{~d}$ & $325.28 \pm 14.68 \mathrm{~d}$ & $19.74 \pm 0.42 \mathrm{a}$ & $12096.89 \pm 599.79 \mathrm{~d}$ & 4.96 \\
\hline & \multicolumn{2}{|c|}{ Under ST, the percentage increase of $6 \mathrm{~K}$ compared to $0 \mathrm{~K} \%$} & & 6.56 & 14.79 & 4.17 & 24.31 & 16.39 \\
\hline & \multicolumn{2}{|c|}{ Under NST, the percentage increase of $6 \mathrm{~K}$ compared to $0 \mathrm{~K} \%$} & & 3.33 & 6.82 & 1.89 & 11.81 & 9.26 \\
\hline & \multicolumn{2}{|c|}{ ST increases the percentage of K effectiveness \% } & & 3.22 & 7.97 & 2.27 & 12.50 & 7.13 \\
\hline \multirow{7}{*}{$\begin{array}{l}\text { Lingnan } \\
\text { warm dry } \\
\text { zone }\end{array}$} & \multirow{2}{*}{ ST } & $6 \mathrm{~K}$ & $80256 \pm 672.71 \mathrm{a}$ & $604.64 \pm 15.99 \mathrm{a}$ & $326.78 \pm 12.21 \mathrm{a}$ & $19.17 \pm 0.37 \mathrm{~d}$ & $12815.56 \pm 571.99 \mathrm{a}$ & 4.46 \\
\hline & & $0 \mathrm{~K}$ & $80313 \pm 994.61 \mathrm{a}$ & $577.36 \pm 17.97 \mathrm{c}$ & $294.12 \pm 12.48 \mathrm{c}$ & $19.74 \pm 0.41 \mathrm{~b}$ & $10945.03 \pm 585.23 \mathrm{c}$ & 5.35 \\
\hline & \multirow{2}{*}{ NST } & $6 \mathrm{~K}$ & $79935 \pm 1927.75 \mathrm{a}$ & $588.84 \pm 14.57 \mathrm{~b}$ & $306.24 \pm 12.86 b$ & $19.54 \pm 0.43 \mathrm{c}$ & $11598.04 \pm 660.44 \mathrm{~b}$ & 5.69 \\
\hline & & $0 \mathrm{~K}$ & $79452 \pm 2043.51 \mathrm{a}$ & $571.48 \pm 15.66 \mathrm{~d}$ & $284.02 \pm 12.44 \mathrm{~d}$ & $19.89 \pm 0.42 \mathrm{a}$ & $10333.19 \pm 646.47 \mathrm{~d}$ & 6.26 \\
\hline & \multicolumn{2}{|c|}{ Under ST, the percentage increase of $6 \mathrm{~K}$ compared to $0 \mathrm{~K} \%$} & & 4.74 & 11.13 & 2.88 & 17.14 & 16.53 \\
\hline & \multicolumn{2}{|c|}{ Under NST, the percentage increase of $6 \mathrm{~K}$ compared to $0 \mathrm{~K} \%$} & & 3.04 & 7.83 & 1.72 & 12.27 & 8.98 \\
\hline & \multicolumn{2}{|c|}{ ST increases the percentage of Keffectiveness \% } & & 1.69 & 3.29 & 1.15 & 4.87 & 7.55 \\
\hline
\end{tabular}




\section{Discussion}

Effects of straw returning combined with potassium fertilizer on the morphological indicators of spring maize stems and stem phenotypic traits

Both straw returning and the application of potassium fertilizer can promote the growth and development of spring maize; the maize plant height, stem diameter, dry matter accumulation of the aerial part of the plant, water content and brix of stems were all increased to varying degrees by these practices [25-27]. In this study, we found that straw returning with potassium fertilizer improved spring maize stem morphological indicators and stem phenotypic traits. The effects of the treatments on each of the tested factors were ranked as follows: $\mathrm{ST}+6 \mathrm{~K}>\mathrm{NST}+6 \mathrm{~K}>\mathrm{ST}+0 \mathrm{~K}>\mathrm{NST}+0 \mathrm{~K}$. These findings are consistent with some studies [28], but not with others [29]. This inconsistency with previously reported results may be due to differences in the time frame of each study. The present study utilized straw returning for consecutive years, while Huijuan Ma conducted experiments with short-term straw returning.

\section{Effects of straw returning with potassium fertilizer on the mechanical properties of spring maize stems}

Both straw returning and potassium fertilizer can significantly enhance the puncture strength, compressive strength and bending strength of spring maize stems, thus increasing maize lodging resistance [30,31]. In this study, straw returning combined with potassium fertilizer significantly improved the mechanical properties of spring maize stems, with the effectiveness of the treatments ranked as follows: $\mathrm{ST}+6 \mathrm{~K}>\mathrm{NST}+6 \mathrm{~K}>\mathrm{ST}+0 \mathrm{~K}>\mathrm{NST}+0 \mathrm{~K}$. These findings are consistent with previous studies [32]. Potassium fertilizer promotes the absorption of potassium by maize, and the absorbed potassium is primarily distributed in the stems, where it contributes to the flexural resistance of stems and has the potential to supplement soil potassium via straw returning at a later stage. Straw returning can increase the available potassium content of the surface soil, yet its direct effect on the aerial part of maize plants is not as pronounced as that of potash application.

Effects of straw returning combined with potassium fertilizer on the grain quality of spring maize

Both straw returning and potassium fertilizer can improve the protein content, crude fat content and starch content of maize grains, and thus enhance maize grain quality [33,34]. In this study, straw returning combined with potassium fertilizer improved spring maize grain quality, with the effectiveness of the treatments ranked as follows: $\mathrm{ST}+6 \mathrm{~K}>\mathrm{NST}+6 \mathrm{~K}>\mathrm{ST}+0 \mathrm{~K}>\mathrm{NST}+0 \mathrm{~K}$. 
Effects of straw returning with potassium fertilizer on spring maize yield

Crop yield is a primary parameter used in the evaluation of the effects of fertilizer application on soil productivity [35]. Potassium fertilizer, straw returning and the combination of straw returning with potassium fertilizer have all been shown to significantly increase spring maize yield [36-38]. In this study, straw returning with potassium fertilizer increased spring maize yield, with the effectiveness of the treatments ranked as follows: ST-6K $>$ NST-6K $>$ ST-0K $>$ NST-0K. These findings are consistent with previous studies $[39,40]$. When potassium fertilizer enters the soil, it is converted into soil-available potassium, which can be directly absorbed and used by maize. In comparison with potassium contained in potassium fertilizer, potassium in maize straw is more easily fixed by the soil and is not readily released. Straw enters the soil after it is returned to the field, and potassium in returned straw must be released by the action of soil microorganisms and enzymes via a long and complex decomposition process. Therefore, potassium in returned straw cannot satisfy the potassium required for the growth and development of maize in the current season. Thus, in comparison with direct application of potassium fertilizer, short-term straw returning has a weaker effect on maize yield.

The variation coefficient of repeated fluctuations in crop yield is an important indicator used to evaluate the disadvantages and advantages of fertilization systems. The main factors affecting the maize yield variation coefficient are soil fertility and soil basic productivity. When the variation coefficient is relatively small, stability is relatively high [41]. In this experiment, the selected optimal model for stable yield was straw returning with potassium fertilizer, and the spring maize yield variation coefficients of the treatments were ranked as follows: ST-6K $<$ ST-0K $<$ NST- $6 \mathrm{~K}<\mathrm{NST}-0 \mathrm{~K}$. These findings are consistent with previous studies [42]. In this study, stable yield was achieved primarily because straw returning with potassium fertilizer improved the soil structure and physicochemical properties, increased soil nutrient levels and soil basic productivity, and provided a suitable environment for the growth and development of spring maize, thus reducing the maize yield variation coefficient and increasing yield stability.

The spring maize stem morphological indicators, stem phenotypic traits, stem mechanical properties, grain quality, and yield varied among the three tested ecological regions in Inner Mongolia, yet the trends in the changes in relevant measurements in each of these areas due to the application of straw returning with potassium fertilizer were extremely similar. Among the tested ecological regions, each of these factors was

101 superior in the Hetao Plain irrigation area, followed by the Tumochuan Plain irrigation area, and finally the 
102

103

130 Conflicts of Interest: The authors declare no conflicts of interest.

\section{$131 \quad$ References}

\section{Conclusions} maize in Inner Mongolia. Station in North China Loess Plateau of China (25204120). field and data collection.

\section{Author Contributions:}

Funding acquisition: Julin Gao, Jiying Sun.

Investigation: Yafang Fan.

Conceptualization: Julin Gao, Jiying Sun, Jian liu, Yafang Fan.

Writing - original draft: Yafang Fan, Jian liu.

Writing - review \& editing: Julin Gao, Jiying Sun.

Lingnan warm dry zone. These differences were mainly due to differences in factors such as basic soil productivity and climatic conditions (sunshine hours, temperature, and rainfall) among the regions.

Among the different treatments, straw returning with potassium fertilizer demonstrated the best effect. Straw returning significantly improved the effectiveness of potassium application on the morphological indicators of spring maize stems, stem phenotypic traits, stem mechanical properties, grain quality, and yield.

In the Tumochuan Plain irrigation area, Hetao Plain irrigation area, and Lingnan warm dry zone, straw returning increased the stem dry weight, water content of stems, brix of stems, stem puncture strength, stem compressive strength, stem bending strength, protein content of grains, starch content of grains, crude fat content of grains, water content of grains, yield and yield variation coefficient by $8.89 \%-11.65 \%$, 1.09\%-1.55\%, 4.35\%-4.50\%, 8.89\%-14.82\%, 6.47\%-11.76\%, 10.89\%-15.69\%, 3.49\%-6.50\%, 0.32\%-0.43\%, $2.09 \%-4.43 \%, 2.75 \%-4.67 \%, 4.87 \%-12.50 \%$ and $5.07 \%-7.55 \%$, respectively. Straw returning with potassium fertilizer improved spring maize stem lodging resistance, while improving grain quality and achieving stable and high yields. This study provides a theoretical basis for high-yield cultivation of stress-resistant spring

Funding: This study was funded by the National Key Research and Development Program of China (2017YFD0300802, 2016YFD0300103), the Maize Industrial Technology System Construction of Modem Agriculture of China (CARS-02-63) and the Fund of Crop Cultivation Scientific Observation Experimental

Acknowledgments: We would like to thank the Maize High-Yield and High-Efficiency Cultivation Team for

Methodology: Jiying Sun, Jian liu, Zhijun Su, Shuping Hu, Zhigang Wang, Xiaofang Yu. 
1321 Zhu Z L, Jin J Y. Fertilizer use and food security in China. Plant Nutrition and Fertilizer Science, 2013,19 (2):

133 259-273. DOI: 10.11674/zwyf.2013.0201

1342 Sun Y R. To explore an effective way to solve the problems of lodging and premature aging in maize 135 densification planting. Modern Agriculture, 2014 (2): 34-35.

1363 Deng Y, Wang C Y, Zhao L, et al. Effects of Population Density on the Stem Traits and Soil Moisture in 137 Maize and Their Correlation with Yield and Lodging Rate. Acta Agriculture Boreali-Sinica, 2017,32 (5): 216-223. DOI: $10.7668 /$ hbnxb.2017.05.032

1394 Gou L, Huang J J, Sun R, et al. Variation characteristic of stalk penetration strength of maize with different density-tolerance varieties. Transactions of the CSAE, 2010, 26 (11): 156-162. DOI: 10.3969/j.issn.1002-6819.2010.11.028

5 CHENG Fu-li, DU Xiong, LIU Meng-xing, et al. Lodging of Summer Maize and the Effects on Grain Yield. Journal of Maize Sciences, 2011, 19 (1): 105-108.

6 Sun S J, Yan Y, Zhang X D. Effects on Soil Moisture under Different Planting Densities with Natural Rainfall Conditions in North-east of China.Journal of Maize Sciences.2011, 19 (2): 90-94. DOI: 10.13597/j.cnki.maize.science.2011.02.027

7 Yu J F. Effects of Long-term Fertilizations on Grain Yield and Quality in Different Quality Wheat Varieties.

1498 Zhao F C. Genotypic Difference for Sweet Maize Grain Quality Traits and Its Response to Environmental Factors. Yangzhou University, 2014.

1519 XIN Li, LIU Jintao, LIU Shutang, et al. Effects of Combined Application of Straw and Organic Fertilizer on Grain Yield and Quality under Wheat Maize Rotation System. Acta Agriculture Boreali-Sinica, 2016, 31 (6): 164-170. DOI: 10.7668/hbnxb.2016.06.026

15410 Khan A W. Mann R A. Muhammad S A M. Integrated potash nutrient management enhances rice productivity under paddy soil. Intern.J.Biol.Biotechnol., 2011, 8 (3): 387-389.

15611 FU Hao-ran, LI Ting-yu, CAO Han-bing, et al. Research on the driving factors of fertilizer reduction in China. Journal of Plant Nutrition and Fertilizers, 2020, 26 (3): 561-580. DOI: 10.11674/zwyf.19365

15812 MEI Nan, LIU Lin, SUI Peng-xiang, et al. Effects of Tillage and Straw Management on Brown Soil 
enzyme activity and maize yield. Soil and Fertilizer Sciences in China, 2019 (5): 25-29. DOI: $10.11838 /$ sfsc. $1673-6257.18482$

16414 CONG Ping, LI Yu-yi, WANG Jing, et al. Effect of one-off bury of different amounts of straws at $40 \mathrm{~cm}$ 165 deep on subsoil fertility. Journal of Plant Nutrition and Fertilizers, 2020, 26 (1): 74-85. DOI: 10.11674/zwyf.19048

15 Shi Zuliang, Shao Yuhang, Wang Fei, et al. Study on the situation and counter measures of straw comprehensive utilization in China. Chinese Journal of Agricultural Resources and Regional Planning, 2018, 39 (10): 30-36. DOI: 10.7621/cjarrp.1005-9121.20181005

16 XU Xiu, FEI Zheng-jun. Effect of Straw Returning with Decomposition Inoculants on Soil Physical-chemical Properties and Yield of Maize. Tillage and Cultivation, 2017, 3: 23-24.

17 WEN Mei-juan, WANG Cheng-bao, HUO Lin, et al. Effects of subsoiling and straw returning on soil physical properties and maize production in Yellow River irrigation area of Gansu, China. Chinese Journal of Applied Ecology, 2019, 30 (1): 224-232. DOI: 10.13287/j.1001-9332.201901.030

18 CHAI Ru-shan, AN Zhi-dong, MA Chao, et al. Potassium resource quantity of main grain crop straw and potential for straw incorporation to substitute potassium fertilizer in China. Journal of Plant Nutrition and Fertilizers, 2020, 26 (2): 201-211. DOI: 10.11674/zwyf.19151

19 Liu Xiaoyong, Li Shutian. Temporal and spatial distribution characteristics of crop straw nutrient resources

20 XIE Jia-gui, HOU Yun-peng, YIN Cai-xia, et al. Effect of potassium application and straw returning on spring maize yield nutrient absorption and soil potassium balance. Journal of Plant Nutrition and Fertilizer, 2014, 20 (5): 1110-1118. DOI: 10.11674/zwyf.2014.0507

21 WANG Zhi-yong, BAI You-lu1, GAO Jin-hua, et al. Effect of straw returned to soil and application of potassium fertilizer on crops yield and soil potassium in the low fertility of efluvo-aquic soil in North contribution to maize yield gain among different locations in China. Maydica. 60-M7:1-7 crop yield, and yield stability in a wheat-maize system [J]. Field Crops Research, 2019, 233:33-40. 
25 WANG Yue-ning, FENG Peng-bo, LI Rong, et al. Effects of Different Straw Returning Methods on Soil Properties and Maize Growth in Yanghuang irrigation area of Ningxia. Southwest China Journal of Agricultural Sciences, 2019, 32 (11): 2607-2614. DOI: 10.16213/j.cnki.scjas.2019.11.019

26 LU Xiao-fang. Effects of Base Potassium Fertilizer on Agronomic Traits and Yield of Density-Tolerant Summer Maize. Journal of Anhui Agricultural Science, 2017, 45 (29): 18-19, 22. DOI: 10.13989/j.cnki.0517-6611.2017.29.007

27 HUA He-liang, ZHAO Qing, ZHOU Yu, et al. Effect of Photosynthetic Characters of Three Ear Leaves on Stalk Sugar Content in Maize. Journal of Maize Sciences, 2016, 24 (3): 92-98. DOI: 10.13597/j.cnki.maize.science.20160315

28 Zhou Jiajia. Effects of straw returning and tillage managements on growth and yield formation of Maize. Shenyang Agricultural University, 2016.

29 Ma Huijuan. Effects of straw application with different years on soil biochemical properties and the development of maize. Jilin Agricultural University, 2016.

30 Wu Cuiqing, Li Nan, Zhang Shuai, Guo Yuming. Study on Mechanical Properties of Air Drying Maize Stalk. Journal of Agricultural Mechanization Research, 2016 (8): 146-150. DOI: 10.13427/j.cnki.njyi.2016.08.031

31 GUO Wen-hui, LIU Qing, SHI Yan-xi. The characteristics of selenium absorption and accumulation in purple sweet potato. Soil and Fertilizer Sciences in China, 2016 (4): 113-117. DOI: $10.11838 /$ sfsc. 20160419

$32 \mathrm{Xu}$ Zhen. Effects of straw mulching on yield and Soil K fertility in wheat-maize rotation system. China Agricultural University, 2016.

$33 \mathrm{Xin} \mathrm{Li.} \mathrm{Effects} \mathrm{of} \mathrm{long-term} \mathrm{fixed} \mathrm{position} \mathrm{straw} \mathrm{returning} \mathrm{on} \mathrm{soil} \mathrm{biological} \mathrm{environment} \mathrm{and} \mathrm{crop} \mathrm{yield}$ and quality. Sichuan Agricultural University, 2015.

34 Gou Caiming. Study on the gcrmplasm identification, selection and optimum cultivation for Luzhou-flavor liquor special maize hybrids. Sichuan Agricultural University, 2015.

35 SHA Zhi-min, BIAN Xiu-ju, ZHENG Wei, LI Wen-juan, HE Ping. Effects of optimum nutrient management on nutrient uptake and utilization of winter wheat in North China Plain. Plant Nutrition and Fertilizer Science, 2010, 16 (5): 1049-1055.

36 Wei Jianlin, Cui Rongzong, Jiang Lihua, et al. Effects of Straw Returning and Application of Potassium Fertilizer under Wheat-Maize Rotation in Fluvo-aquic Soil Area. Shandong Agricultural Sciences, 2018, 
bioRxiv preprint doi: https://doi.org/101101/2021.04 19.440424; this version posted April 19, 2021. The copyright holder for this preprint (which was not certified by peer review) is the author/funder, who has granted bioRxiv a license to display the preprint in perpetuity. It is made available under aCC-BY 4.0 International license.

22337 Liu P, Shao Y T, Wang Z G, Tang Y L, Wang J W. Effect of nitrogen reduction on yield stability of sweet maize//soybean intercropping system in South China. Chinese Journal of Eco-Agriculture, 2019, 27 (9): 1332-1343. DOI: 10.13930/j.cnki.cjea.190129

38 TAN De-shui, JIN Ji-yun, HUANG Shao-wen, LI Shu-tian, HE Ping. Effect of Long-Term Application of K Fertilizer and Wheat Straw to Soil on Crop Yield and Soil K Under Different Planting Systems. Scientia Agricultura Sinica, 2007, 40 (1): 133-139.

39 TAN De-shui, JIN Ji-yun, HUANG Shao-wen, GAO Wei. Effect of long-term application of potassium fertilizer and wheat straw to soil on yield of crops and soil potassium in fluvo-aquic soil and brown soil of northcentral China. Plant Nutrition and Fertilizer Science, 2008, 14 (1): 106-112.

40 Gong Zhenping, Deng Naizhen, Song Qiulai, Li Zhongtao. Decomposing characteristics of maize straw returning in Songnen Plain in long-time located experiment. Transactions of the Chinese Society of Agricultural Engineering, 2018, 34 (8): 139-145. DOI: 10.11975/j.issn.1002-6819.2018.08.018

41 Duchene O, Vian J F, Celette F. Intercropping with legume for agroecological cropping systems: Complementarity and facilitation processes and the importance of soil microorganisms: A review. Agriculture, Ecosystems \& Environment, 2017, 240: 148-161. 
bioRxiv preprint doi: https://doi.org/10.1101/2021.04.19.440424; this version posted April 19, 2021. The copyright holder for this preprint (which was not certified by peer review) is the author/funder, who has granted bioRxiv a license to display the preprint in perpetuity. It is
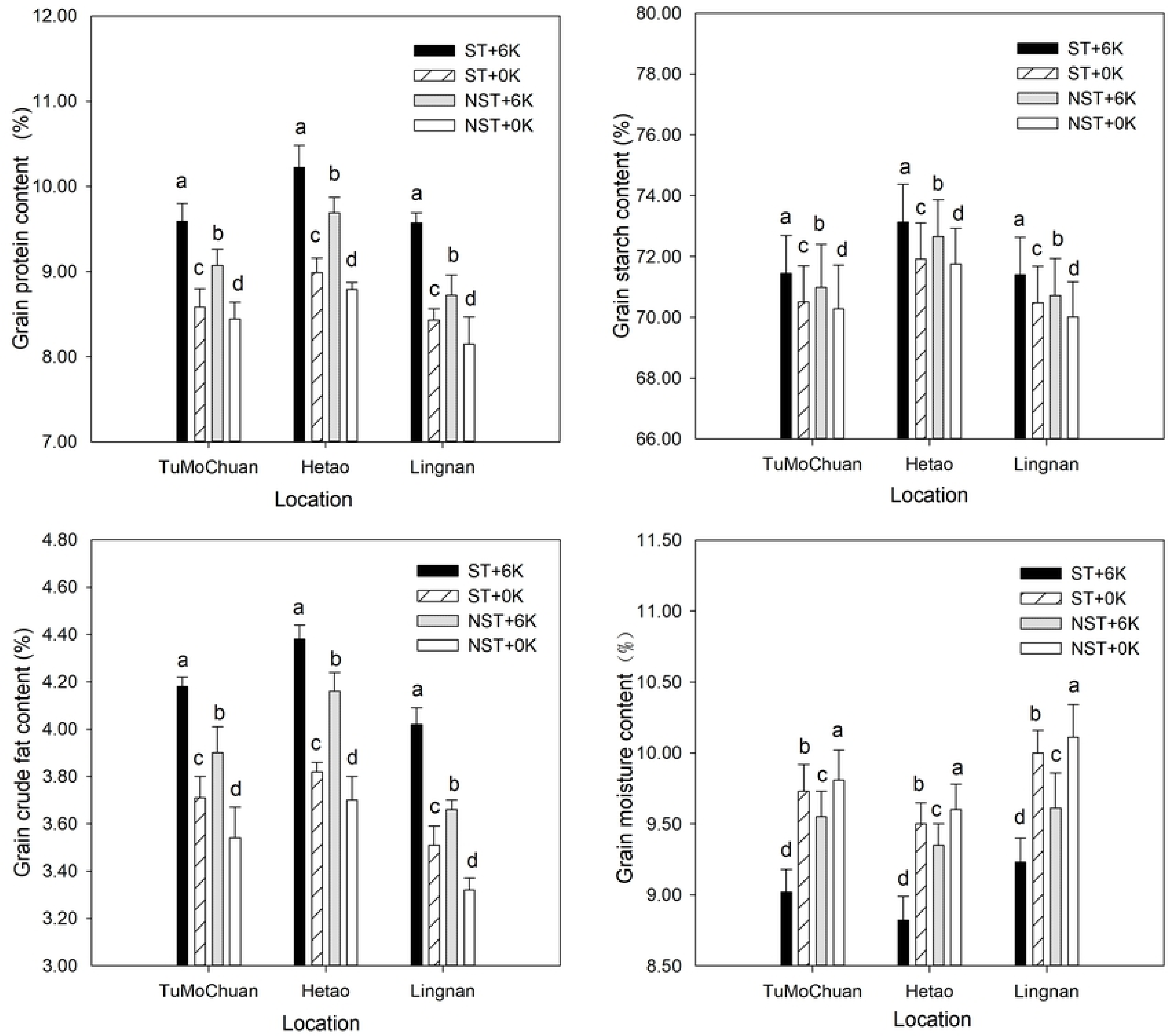

Figure 2 